\title{
婦人靴下の撰別作業室の照明と 混合光源の演色性の評価
}

\section{正会員 松田宗太郎 ${ }^{*}$ 正会員 浦田利夫* 正会員 水野秀夫**}

\author{
Lighting A Women's Stocking's Color-Matching Workshop \\ and
}

An Evaluation of Color Rendering Properties of Mixed Light Sources.

By Sotaro Matsuda (Member) and Toshio Urata (Member), Hideo Mizuno (Member)

(Matsushita Electric Industrial Co., Ltd. 5 th Business Dept.)

\begin{abstract}
Color rendition of light source is very important factor in a lighting design for inspection of textile goods. This thesis describes examination and its theoretical consideration, which the writers made at Ayabe Factory of Gunze Spinning Company in relation to proper light source in the sorting work-shop for matching colors of stockings for women.

According to the examination, the most proper light source for sorting work of fresh-colored women's stockings is mixed light sources. Combinations of such light sources are :
(1) $($ FL-40D-DL) $+($ FL-40W-DL $)+($ IL-100) $\times 2$
(1) $40 \mathrm{~W}$, De laxe Daylight ${ }^{+} 40 \mathrm{~W}$, De laxe White 2 of $100 \mathrm{~W}$, incandescent lamp
(2) $(\mathrm{FL}-40 \mathrm{D})+(\mathrm{IL}-100) \times 1$

(2) $40 \mathrm{~W}$, Daylight 1 of $100 \mathrm{~W}$, Incandescent lamp

The goods inspected by these mixed light sources were inspected again by day light from north-side window at noon and no inspection mistakes were almost found out.

Finally it was concluded, as the results of theoretical consideration in comparing these mixed light sources with standard light source, that the most proper combination of light sources is a system of the above ( 2 ).
\end{abstract}

\section{内 容 梗 概}

䋐維製品の検查照明には光源の演色性が極めて重要である. 本論文は郡是製糸株式会社綾部本工場における 婦人靴下の色合せの芯めの撰別作業室の適性光源につき, 筆者等の行った夹験およびその理論的考察を述べた ものである。

すなわち肌色の啸人鞉下の撰別作業に最適光源は本実験では混合光源によるものであり，その組合せは，

$$
\text { (1) } \begin{array}{cc}
(\mathrm{FL}-40 \mathrm{D}-\mathrm{DL}) \\
40 \mathrm{~W} \text { 天然昼光色 }
\end{array}
$$

(2) $(\mathrm{FL}-40 \mathrm{D})+(\mathrm{IL}-100) \times 1$

40 W笪光色 $\quad 100 \mathrm{~W}$ 白熱電球 1 ケ

といら結果在得た。

これ等の混合光源により㛟査し·た品を，再び正午の北空光により蚞査し·たが，蚞査ミスはほとんど皆無であ $っ た$.

しかし.てこの混合光源を標準光源と比較してて理論的考察を行った結果は(2)の組合せによるものが最適という ことななった.

はしがき

戦後, けい光灯恃異常な勢で進步発展し., 世は正にけ い光灯時代といった感がある.これはけい光灯の持つ幾 多の特徵がしからしむる処であらが, なかんづく, 能率 $(\mathrm{Lm} / \mathrm{W})$ の良いことが大いに 影響してていっものと考光

* 松下電器产藩株式会社 第 5 事業部. 照明技術課。

**松下電子工悉株式会社 溃光灯部。技術課
られる。すなわち，一応経济的限界に来ていた白熱電球 による照度が容易に増大できたためであるう。

かくし.て照明の量的問題が解決し.て来ると, 人類の欲 求は更に畫きるところを知らず，従来全く問題にされな かった演色性が重要視されいわゆる光の量のみならず, 光の質に対する要求が蟲まってきた。

その一例としてて, 今回郡是製系綾部本工場に於ては, 
ナイロン婦人靴下の製造の際，その検査工程中，左右の 靴下の色合せの作業が従来演色性の関係で 昼間の又に 行われていたのであるが，自然光によるといえどもなお かつ四季天候汇岕る程度影锌され，必ずし.も満足な效果 を挙げていなかったことに鑑み，これを改良し、理想的な 人工光線の下で作業を実施し.，以って能率の向上と品質 の均一化を図るということが強く要望される礼る至った。

このため，昭和29年 4 月未より綾部本工場汇於て種々 の寒唤を行い，添涪満足すべき結果を得たが，さらにそ の理論的裏付们つき研究したところ，実際的実駼死確証 らける成績を得た。

その後もなお引続き研究中でするが，こ」そ中間報告 とし.て研究の概要を御紹介寸。。

\section{1. 郡是製糸 KK ナイロン靴下検查室における演 色性の実験}

\section{A 実験月日 昭和29年 4 月26日 \\ B 実験目的}

婦人用ナイロン靴下の娭查については，従来は睛天の 日の昼間にの文行っていたが，雨天の日及び夜間の作業 が可能のような光源を得ると同時汇，各種光源の演色性 の理論的評価値を測定し.，梚查の根拠とし.たいといらの がその目的である。

\section{C 実験方法}

現在人工光源仙いても最も自然光汇近いものを得る には，ょり優れた天然色型けい光灯を製作することと，

各種の光源より混合するいわ肪る Mixing Illumination Method とが考えられる。

天然色型けい光灯は，現在わが国小よび米国化小いて も研究，発達の途上市りり，日進月歩では山るが極めて 高度の演色性を要求される時汢 現在の天然白色または天 然是光色の及の使用では㴖足できない模様である。従。 て今回は，電球と各種けい光灯の混合照明を主体とし.て 実験を行った。

\section{D 実験の状況}

（a）検查台の平均照度が $250 \mathrm{~lx}$ 亿なるよう光源の高 さを調節し，第 1 表の如き組合せとよりナイロン鞉 下を照明し.左右の靴下の色合せ唡查を行った。

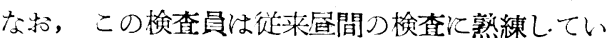
る女子作業員 5 名を採用し・た。

（b）上上の結果から最も演色性の上い光源は

天登 $(40 \mathrm{~W})+$ 天白 $(40 \mathrm{~W})+100 \mathrm{~W}$ 電球 2 ケ

天屋 $(40 \mathrm{~W})+$ 天白 $(40 \mathrm{~W})$

笪光 $(40 \mathrm{~W})+100$ 電球

ということになったが，この光源の下で検查したもの と，昼間険査し·たものとの差を調べるために，この光
源の下で靴下を検查し，望日昼間自然光の下（晴天， 北向の空際，午前 9 時敊よび12時）で同様検植を行っ た結果

天篂 $(40 \mathrm{~W})+$ 天白 $(40 \mathrm{~W})+100 \mathrm{~W}$ 電球 2 \%

堅光色 $(40 \mathrm{~W})+100 \mathrm{~W}$ 電球

が第 2 表のごとく非常に優秀な結果を收めた。

\section{第 1 表}

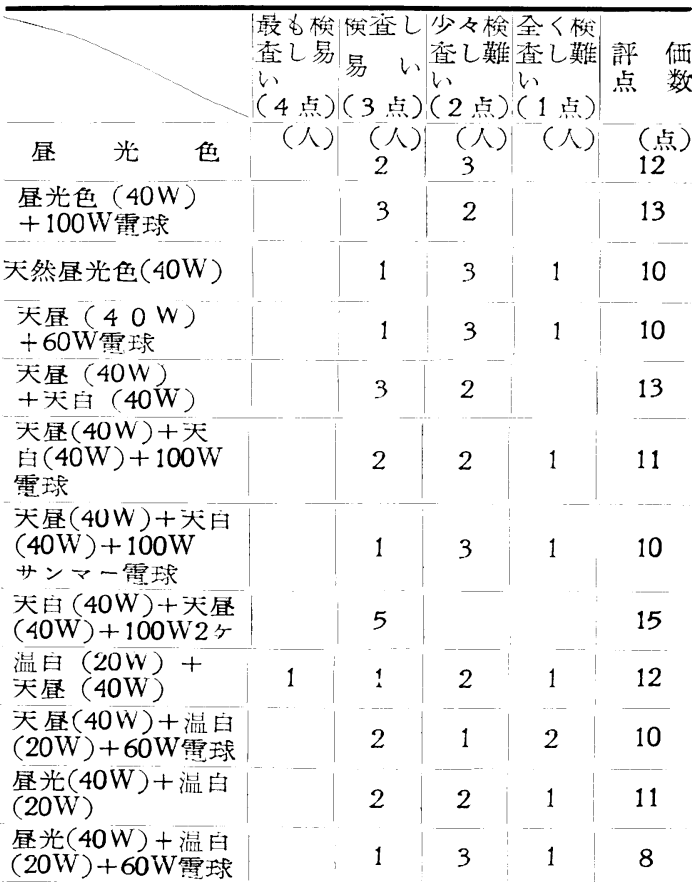

註（1）霓球は全部フロスト霓球を使用。

(2)温白色计い光灯のみは $20 \mathrm{~W}$ ，他のけい光灯々い ずれも40Wである。

(3) 㭘査台の平均照度は $250 \mathrm{~lx}$ である.

第 2 表

\begin{tabular}{|c|c|c|c|}
\hline & 検绎数 & 合格数 & 合格率 \\
\hline 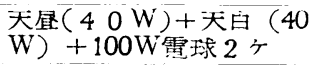 & $\begin{array}{l}\text { (足) } \\
20\end{array}$ & $\begin{array}{l}\text { (足) } \\
20\end{array}$ & $\begin{array}{l}(\%) \\
100\end{array}$ \\
\hline 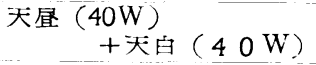 & 20 & 13 & 65 \\
\hline 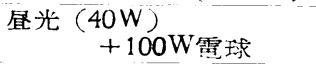 & 50 & 47 & 94 \\
\hline
\end{tabular}

以上のごとくであるが，この実験に対する理諭的評価 とし・て次のごとき考察を行った。

\section{2. 前㲹の実驗に対する理論的考察}

A けい光灯の色票に対する効果の計算

各光源の演色性の良否を判別する方法江は，従来は同 時比較といって未知色票と既知色票の耐色曹を同時的に 調查測定する方法で，この方法怯演色性というものがさ ほど問題にならなかった時代の方法で，所謂人間の眼の 
色順応という点が考慮に入れておらなかった。然し.現在 で注本格的な演色性の研究の進歩汇上り，眼の色順応も 考慮江入れられ，(1)継時比較法（記憶等色法）(2)両眼視 等法等，実際汇調べる方法が発表されているが，こ」で は，東，森2)両氏が行った色票のずれを量的に表示する 方法をら用し、奏際に測色計算を行ってみた。

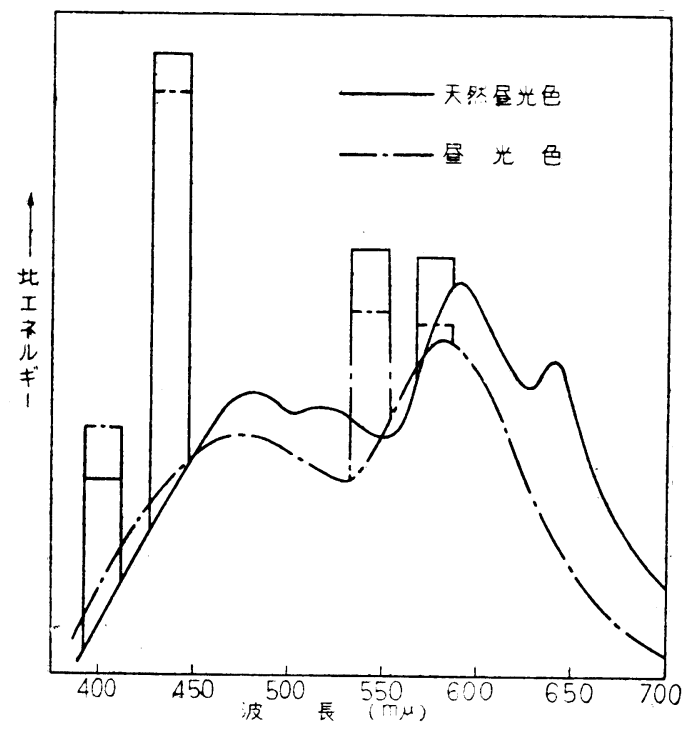

第 1 図 昼光色括よび天然冝光色けい 光灯の分光ェネルギー分布困

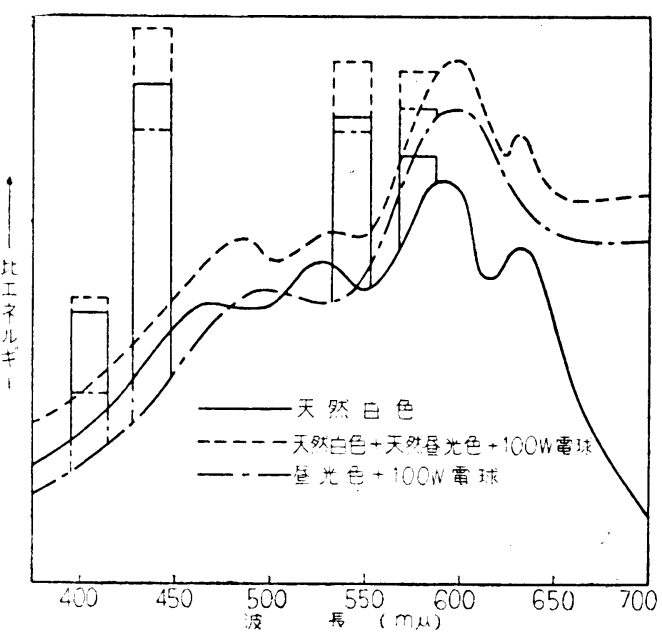

第 2 図天然白色拈よご混合光源の エネルギー分布図

これ汇代表的な各色票の分光反射率々各光源のスぺ クトル分布曲線から测色計算を行って 標準光源との差を 比較するもので，標準光源とし.ては冝光色けい光灯に関 しては平均㫫光を用いるかが当然であるが，こ」では平

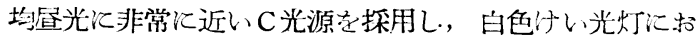
いては $4500^{\circ} \mathrm{K}$ Black Body Radiater 学用いる事化し.た。 色物の試料とし.ては，実在与る色学公く蔽うものとしてて 色票を用いることにしそこで “標淮色名法汇占る色票” :)3) の内, 赤 $(\mathrm{R})$, 黃赤 $(\mathrm{YR})$, 黄 $(\mathrm{Y})$, 黄緑 (GY), 緑 $(G)$, 青緑 $(B G)$, 青 $(B)$, 青紫 $(P B)$, 紫 $(P)$, 赤紫 (RP)，の純色，10色相を採用し.た。この分光区射率は分

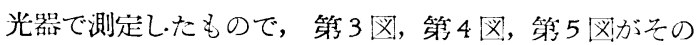
值である。

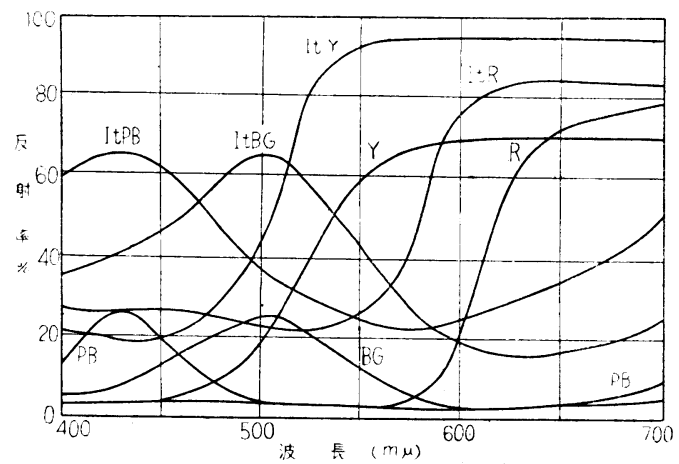

第 3 図試㪴色票の分光反射率分布

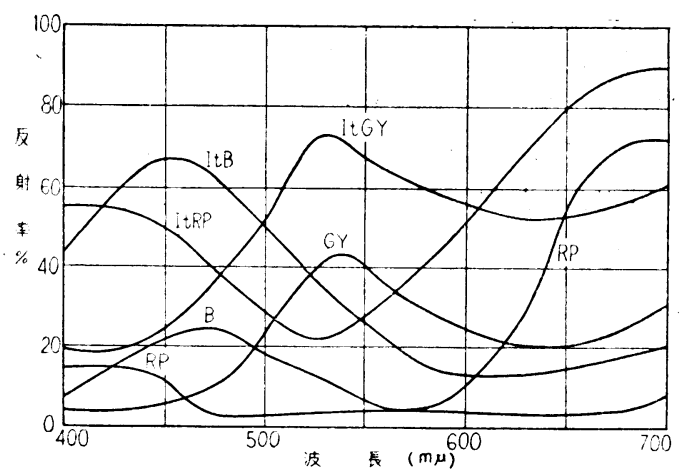

第 4 図試料色票の分光反射率分布

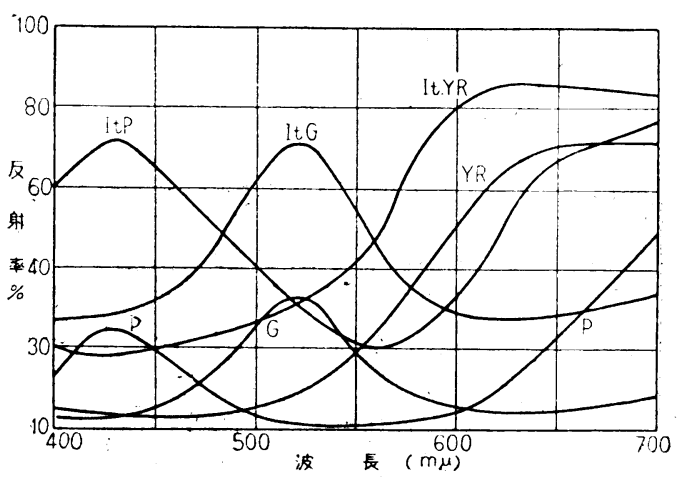

第 5 図試料色票の分光反射率分布 
測色計算は上記の分光反射率曲線，スペクトル三刺陪 值 $\bar{x} . \bar{y} . \bar{z}$ 备光源のエネルギー分布図の波長を $10 \mathrm{~m} \mu$ の

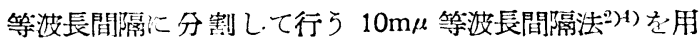
いた。

洨扮，水銀線スペクトルによる部分は，各線スペクト ル波長について別汁算し、て加党合世た。

$E_{\lambda}$ 分光ェネルギー值

$\rho_{\lambda}$ 分光反射率 (JIS 規格完全反射面 $\mathrm{MgO}$ を 100\%とする)

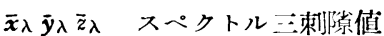

$E_{i}$ 輝線スペクトルに和ける分光エネルギー值

$\rho_{i}$ 輝線スペクトルに拈计る分光反射率

$\overline{\boldsymbol{x}}_{i} \bar{y}_{i} \bar{z}_{i} \quad$ 輝線スペクトルに拉ける三剌钱値

$$
\begin{aligned}
& X=\sum^{n} E_{i} \bar{x}_{i} \rho_{i}+\int_{3 \times 1}^{i r 0} E_{\lambda} \bar{x}_{\lambda} \rho \lambda d \lambda \quad x=\frac{X}{X+Y+Z} \\
& Y=\sum_{1}^{n} E_{i} \bar{y}_{i} \rho_{i}+\int_{i s 01}^{7 E_{\lambda}} y_{\lambda} \rho \lambda d \lambda \quad y=\frac{Y}{X+Y+Z} \\
& Z=\sum_{1}^{n} E_{i} \bar{z} i \rho_{i}+\int_{3 \times 0}^{E_{\lambda} \delta 0} \bar{z}_{\lambda} \rho_{\lambda} d \lambda \quad z=\frac{Z}{X+Y+Z}
\end{aligned}
$$

以上のようにし、て算出さ礼た色度は，反射率を改良、 ンセル系に換算し.等感覚差の座標值してて色ずれの大き さ走示した。

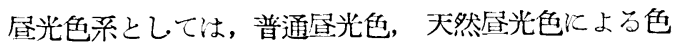
票の色度，与なわ $x . y$ ちの值な C光源の色度 $(x . y)$ との 值と比較した図が第6図でこの色度を Munsell Notation'江換算し，明度 (Value) のずれさ示したのが第 7 困である。李た第 8 図はC光源からの色相，彩度のずれ を示し・たものである。

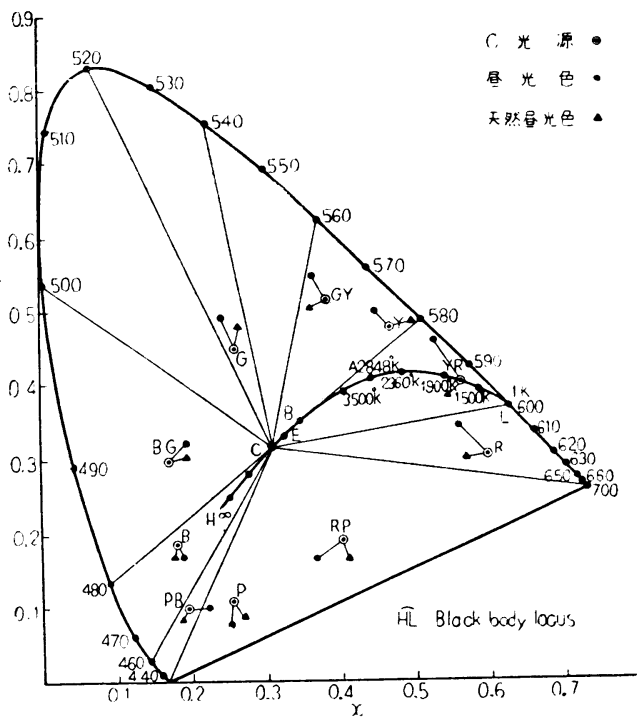

第 6 図 昼光色 $\left(6,500^{\circ} \mathrm{K}\right)$ 光源で照明 した特の色の色度

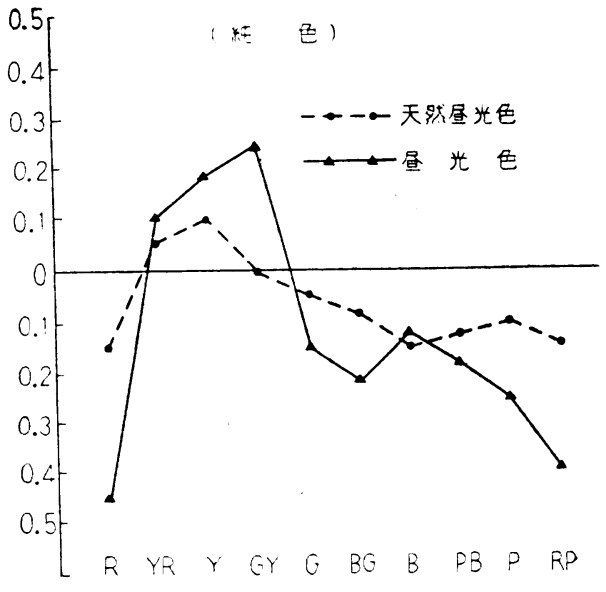

第 7 困色曹の明度ずれ

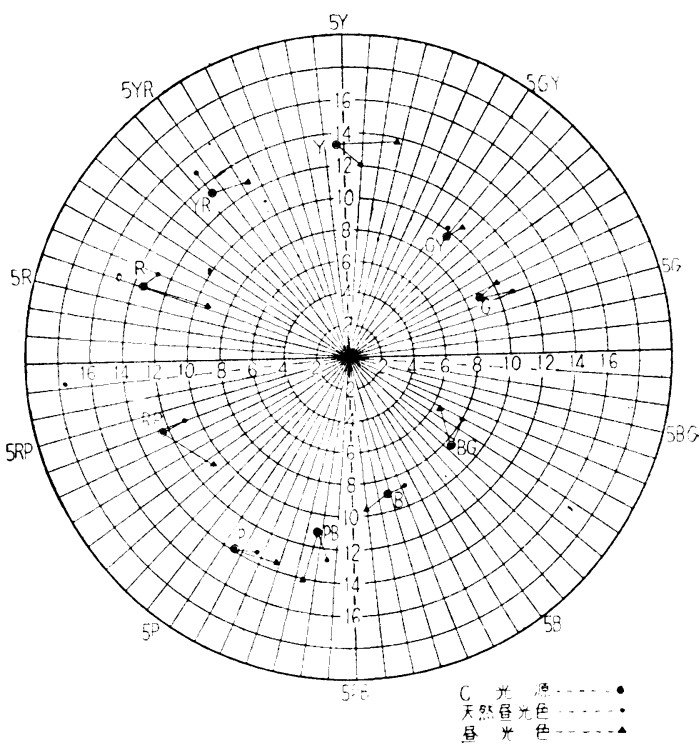

第 8 図色票の色相彩度の変化

同様に白色系の光源については $4,500^{\circ} \mathrm{K}$ Black Body Radiater と比較しなた值を示すと第9〜11园のようにな ๖.

B 計算結果

以上の計算結果を全般的に見て下記の事項が上げら れる。

I 普通屋光色けい光灯の演色性

1. 赤 $(R) の$ 色相は光源と比較し.てほとんど恙はない が，彩度敊よび明度が下っている。

2. 黄赤 (YR)の色票は黄 (Y)の方にかたよっている が，彩度はほとんど C 光源の彩度の值と変らない。

3. 黄赤 $(\mathrm{YR})$, 黄( $\mathrm{Y})$ の明度は上っている. 
4. 黄(Y)の色相は緑黄(GY)の方偏って扮り, 彩度 む若下上っている。

5. 緑黄 (GY) の彩度恃若干上っているが，色相怡ほ とえどC光源と変らない。

6. 緑黄(GY)の明度㹥下っている。

7. 緑 $(\mathrm{G})$ の色相は光源と大美はないが彩度は若干上 っている.

8. 青緑(BG), 青(B)の色相緑( $(G)$, 紫赤 $(P R) の$

方に偏っている。驿明度及び彩度が下っている。

9.紫青(PB)の色相はほとんど变らないが，彩度は上 っている.

10. 紫 $(\mathrm{P})$ の彩度は $\mathrm{C}$ 光源淿比較し.てほとんど差はな いが，色相が紫青(PB) と偏っている。

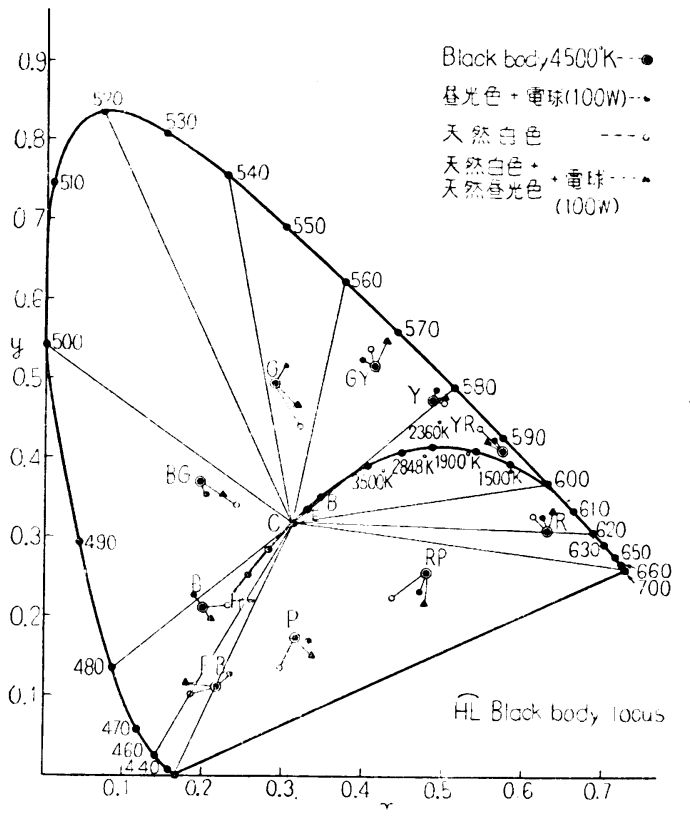

第 9 図白色 $\left(4,500^{\circ} \mathrm{K}\right)$ 光源で照明 した時の色曹の色度

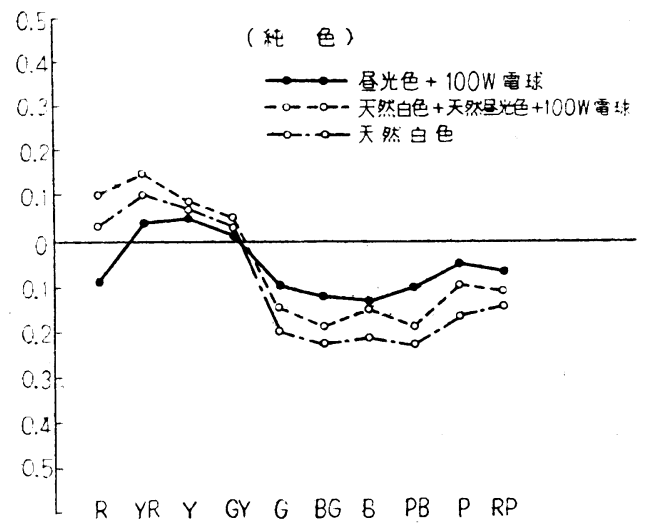

第 10 図色票の明度ずれ

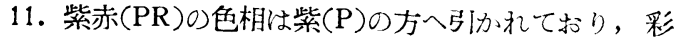
度および明度は下っている。

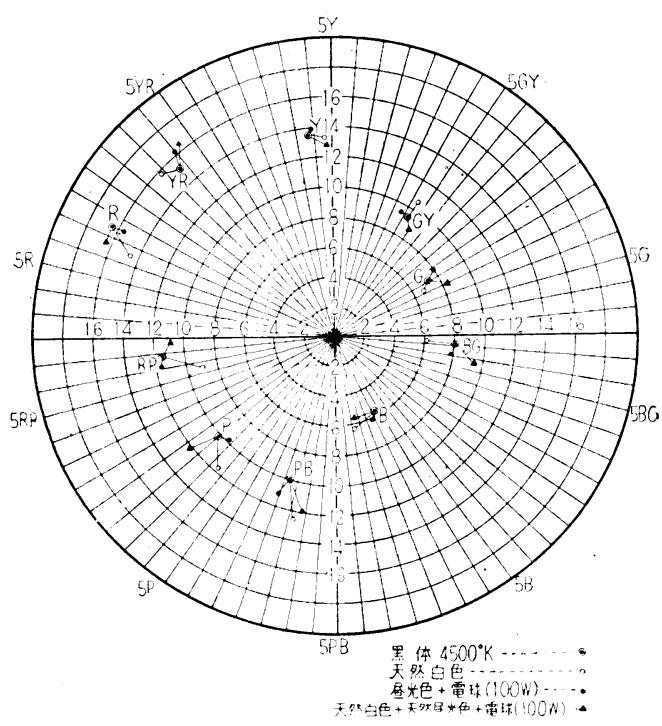

第 11 図色票の色相彩度の変化

II 天然白色，天然昼光色忛い光灯の演色性

1. 天然色忛い光灯では，白色および㡺光色けい光灯 の色票のずれを非常に良く改善し、ていら。乙かしま だ充分滿足できるとはい党ない。

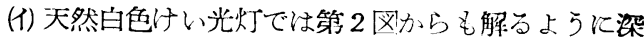
赤色の部分のみが改良されたのではなく，全波長 非にわたって改良されているため，全般的色票 のずれが少い， 然し·緑(G)から紫青(PR)までの 色票の明度が 他の色票に比較してて若干ずれが大 きい。

2. 天然尽光色十い光灯は天然白色忛い光灯に比較し て樑赤色部分のエネルギーが僅か少ないが，青系統 の部分が天然白色上り多いため，全般的に色票のず れが少ない。

（〕）天然白色に比較してて深赤色部のエネルギーが僅 か少ないたる，赤( $\mathrm{R}) の$ 明度が若干下っている。然 L.天然昼光色性緑 $(\mathrm{G})$ 加ら赤紫 $(\mathrm{RP})$ までの色相, 彩度および明度がC 光源と比較してて差が少ない。

III 混合光源の演色性

1. 天然白色十天然昼光色十電球 (100W) 2 ケ (T) 赤 (R) の色票に関し.ては天然寔光色よりも標準 光に近いが，天然白色に比較すると若干明度が高 い方にずれている。

（可）緑から赤紫までの色票の明度㹥 天然白色より標 準光源江近心。

2 . 昼光色 +100 W電球 $(1$ ケ 
この混合光源は上上の五つの 光源中最も演色性の 優秀な光源である。

(T) 天然白色妨よび天然㡺光色では，特に黄色 $(\mathrm{Y})$ 号よび緑 $(\mathrm{G})$ から $(\mathrm{P})$ 紫までの明度を低下さ然てい っが，この混合光源は標淮光源とほとんど美が注 认程度改善し.ている。

(可) 前記の混合光源(天白+天是 $+100 \mathrm{~W}$ 電球 (2 ケ) で青(B)の色相が青紫(BP)に偏っているのを芫全 に補正し.ている.

(へ) 赤系の補正が天然色けい光灯より十分で岁るた め，標準光源使と近ずいている。

$\Leftrightarrow$ 全色票の色相, 彩度, 明度のずれの量は上上の 五つの光源中最も少なく，標淮光源佂一番近い。

以上計算結果走前揭照明学界誌, 東, 森雨氏の論文之

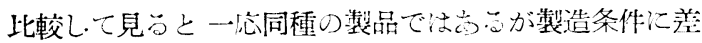
が岕るため 分光エネルギーが多少異って現われている。

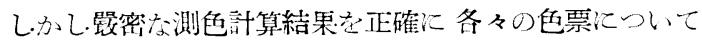
検討し.てみると差怯認められるが，全般的な結果性同じ

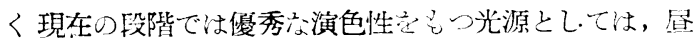
光色+100W電球沉なっている.

\section{3. 結 論}

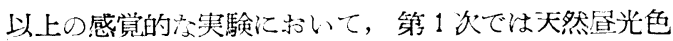
十天然白色 $+100 \mathrm{~W}$ 電球 2 ケが最当演色性良好で，㡺光 色+100W電球 1 ケが第 3 位程度となったが, 第 2 次では 昼光色 +100 W電球が第 2 位上なり,さらに最後の㗇重な 測色計算から性昼光色 $+100 \mathrm{~W}$ 電球が最も優秀な結果を 得る洷っている。 これらの変化の原因とし.て次の事項 が考えられる。
1 実験回数㐨よび 対象人員が若干少なかったこと。

2 実験者怙相当同作業江熟練し・た者であるが肉眼で この二光源の演色性の良否を判断することができな いこと.

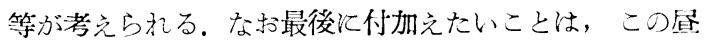
光色電球が他の光源を使用する場合の器具より, 照明設 計的汇非常江有利で岕ることで，ナイロン鞉下の色ずれ の量恃寔光色 +100 W電球の場令と, +天然白色天然昼光 色 $+100 \mathrm{~W}$ 電球の場令とでは实駼, 测色計算共にさ添ど の差はなく,どちらの光源を使用してても大きな検罡上の 差は组ないもの上考完られる。

し.か乙.实際江大きな㭘查場へ取付什る場会は，経済的 で照度分布状沇の良い検查し.易い光源でなけ礼ばならな い. 従っ て40W 2 灯用の器具飞天然白色, 天然居光色老 取付计て（100Wの電球怯抬照型反射笠村で别に取付け る). 照明与るよりも40W 1 灯用の器具（㡺光色 $+100 \mathrm{~W}$ 電球）を用、器具台数起 2 倍にし.て照度分布圭より均一。 にし・た方が，実祭の大きな梌查場とし、ては適当で岕ると 考光られる。

别図泭器具配置去示すのである。

いずれてせよ，近時行い光灯の演色性がやかるてくい われる折柄，その実用的の立場と，之の研究の立場上の 両者から研究し得たことが，業界の進展汇何等かの参考 ともなれば幸甚で岕る。

\section{4. 実 施 例}

$36 \mathrm{~m} \times 9 \mathrm{~m}$ の検查室汇前述の如き演色性を有する全般 照明を試多た。光源の配圆及び照度分布を別困に示主。

この設備の効果汇ついては, 目下調查表を作成し.調查

第 3 表 各光源で色票を照した場合のマンセル記号

\begin{tabular}{|c|c|c|c|c|c|c|c|}
\hline 色 紫 & C 光 源 & $\underset{\text { body }}{4500^{\circ} \mathrm{KBlcak}}$ & $\begin{array}{c}\text { 冝光色十霓球 } \\
(100 \mathrm{~W})\end{array}$ & $\begin{array}{l}\text { 天然冝光冝 } \\
\text { 天然色 } \\
(100 \mathrm{~W}) \text { 需球 }\end{array}$ & 天然 白色 & 天然冝光色 & 昼 光 色 \\
\hline $\mathrm{R}$ & $6 \mathrm{R} 3.8 / 14.1$ & $8 \mathrm{R} \quad 4.0 / 16.0$ & $7.5 \mathrm{R} 3$ & $6.5 \mathrm{R} 3.8 / 16.2$ & $6 \mathrm{R} 3.9 / 14.5$ & $6 \mathrm{R} 3.6 / 13.0$ & $6.5 \mathrm{R} \quad 3.3 / 9.2$ \\
\hline Y R & 4 YR5.6/13.7 & 3 YR5.9/15.3 & 3.5 YR5.9/16.4 & 4.5 YR5.8/16.6 & 2.5 YR5.7/15.8 & 4 YR5.6/15.1 & 7 YR 5.7/12.8 \\
\hline $\mathrm{Y}$ & $5 \mathrm{Y} 7.7 / 11.4$ & $3 Y 7.9 / 13.8$ & $3.8 Y 7.85 / 13.8$ & $4.5 Y 7.8 / 13.9$ & $4.5 Y 7.8 / 13.3$ & $6 \mathrm{Y} 7.8 / 12 . \mathrm{i}$ & $8.5 Y 7.8 / 13.8$ \\
\hline G Y & 6 GY6.3/ 9.4 & 4 GR6.2/ 9.5 & $3.5 \mathrm{GY} \quad 6.2 / 9.5$ & $4.5 \mathrm{GY} 6.2 / 8.6$ & $3.8 G Y 6.2 / 10.6$ & $6 \mathrm{GY} 6.3 / 11.1$ & $6.5 \mathrm{GY} 6.2 / 10.5$ \\
\hline G & $3 \mathrm{G} \mathrm{4.7/9.0}$ & $2 \mathrm{G} 4.5 / 9.2$ & $1 \mathrm{G} \quad 4.4 / 7.8$ & $3 \mathrm{G} \quad 4.3 / 8.4$ & $3 \mathrm{G} \quad 4.3 / 6.5$ & $4 \mathrm{G} 4.5 / 10.8$ & $3 G \quad 4.6 / 9.8$ \\
\hline$B$ G & 7 BG3.7/ 8.3 & $2 \mathrm{BG} 3.6 / 8.0$ & $2.5 \mathrm{BG} 3.5 / 7.6$ & $3.8 \mathrm{BG} 3.4 / 9.6$ & $1 \mathrm{BG} 3.4 / 5.9$ & $9 \mathrm{BG} 3.6 / 8.0$ & $9 \mathrm{BG} 3.5 / 6.5$ \\
\hline $\mathrm{B}$ & $2 \mathrm{~PB} 3.1 / 8.5$ & $8 \mathrm{~B} 2.9 / 5.5$ & $9 \mathrm{~B} \quad 2.8 / 6.0$ & $1 \mathrm{~PB} 2.5 / 12.0$ & $2.5 \mathrm{~PB} 2.8 / 6.4$ & $9 \mathrm{~B} \quad 2.9 / 8.8$ & $4.5 \mathrm{~PB} \quad 3.0 / 9.0$ \\
\hline P B & $8 \mathrm{~PB} 2.2 / 11.2$ & $10 \mathrm{~PB} 2.0 / 12.0$ & $1 \mathrm{P} \quad 1.9 / 11.2$ & $8 \mathrm{~PB} 1.8 / 5.6$ & $8.5 \mathrm{~PB} 1.8 / 12.6$ & $7 \mathrm{~PB} 2.1 / 12.8$ & $8.5 \mathrm{~PB} 2.0 / 14.3$ \\
\hline $\mathrm{P}$ & $3 \mathrm{P} 2.3 / 14.0$ & $9 \mathrm{P} 2.2 / 10.4$ & $8.5 \mathrm{P} 2.1 / 9.8$ & $9.7 \mathrm{P} 2.05 / 12.3$ & 6.5 P $2.05 / 11.8$ & $2.5 \mathrm{P} 2.2 / 13.4$ & $1 \mathrm{P} \quad 2.1 / 13.5$ \\
\hline R P & 4 RP3. $1 / 12.3$ & 8.5 RP $3.1 / 11.1$ & 7.2RP3.05/11.7 & 9.8RP3.0/12.8 & $6 \mathrm{R} \mathrm{P} 3.0 / 9.0$ & $4 \mathrm{R} \mathrm{P} 2.9 / 11.0$ & $9.5 \mathrm{P} 2.7 / 11.0$ \\
\hline
\end{tabular}


中であるが，今迄の調査の状況を見ると非常に好評であ る.

この研究を行うに当り, 神戸大学工学部品川教授, 郡 是製系総部本工場馬場工場長, 非上工務課長, 吉野施設 課長，米井主任より御指導御援助を頂いたことを厚く感

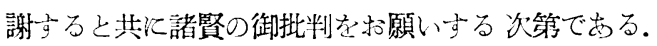

(昭29-10-11受付)

\section{交 献}

1. S. M. Newhell, D. Nickerson, D.B. Judd : J. O.S.A.33, 385(1943)

2. 東, 森氏 : 照学誌 (昭27-8)

3. 色彩科学協会：「標準色名」(昭26)

4. B. Boast : Illumination Engineering Warren, ¿ ed Ed (1953)

第 4 表各光源の $\mathrm{x}$. $\mathrm{y}$ 艾で色湜度との関係

\begin{tabular}{|c|c|c|c|c|c|c|c|c|c|c|c|c|c|c|c|}
\hline & 光 源 & $\mathrm{C}$ 光 & 七 源 & $\begin{array}{r}4500^{\circ} \mathrm{K} \\
\text { boc }\end{array}$ & slack & 亘光色 & 十電球 & 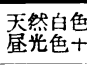 & 天然 & 天然 & 白色 & 天然冝 & 光色 & 昼 光 & 色 \\
\hline & & $\mathrm{x}$ & $\mathrm{y}$ & $\mathrm{x}$ & $\mathrm{y}$ & $\mathrm{x}$ & $\mathrm{y}$ & $\mathrm{x}$ & $\mathrm{y}$ & $\mathrm{x}$ & $\mathrm{y}$ & $x$ & $\mathrm{y}$ & $x$ & $\mathrm{y}$ \\
\hline & $\mathrm{R}$ & 0.590 & 0.310 & 0.629 & 0.314 & 0.625 & 0.325 & 0.635 & 0.332 & 0.615 & 0.325 & 0.566 & 0.296 & 0.531 & 0.326 \\
\hline & Y R & 0.556 & 0.412 & 0.574 & 0.408 & 0.560 & 0.425 & 0.555 & 0.435 & 0.543 & 0.435 & 0.545 & 0.376 & 0.526 & 0.434 \\
\hline & Y & 0.451 & 0.476 & 0.487 & 0.475 & 0.487 & 0.483 & 0.502 & 0.485 & 0.495 & 0.467 & 0.489 & 0.487 & 0.445 & 0.495 \\
\hline & G Y & 0.376 & 0.521 & 0.409 & 0.514 & 0.395 & 0.523 & 0.425 & 0.536 & 0.415 & 0.530 & 0.365 & 0.506 & 0.376 & 0.545 \\
\hline & G & 0.256 & 0.450 & 0.278 & 0.498 & 0.301 & 0.506 & 0.312 & 0.465 & 0.317 & 0.445 & 0.263 & 0.476 & 0.249 & 0.475 \\
\hline & $\mathrm{B} \mathrm{G}$ & 0.170 & 0.300 & 0.191 & 0.369 & 0.208 & 0.352 & 0.220 & 0.365 & 0.240 & 0.340 & 0.195 & 0.306 & 0.191 & 0.320 \\
\hline & B & 0.178 & 0.186 & 0.190 & 0.235 & 0.175 & 0.224 & $0.210^{\prime}$ & 0.185 & 0.220 & 0.213 & 0.186 & 0.169 & 0.188 & 0.165 \\
\hline & P B & 0.191 & 0.100 & 0.220 & 0.139 & 0.235 & 0.125 & 0.175 & 0.133 & 0.185 & 0.110 & 0.183 & 0.085 & 0.221 & 0.100 \\
\hline & $\mathrm{P}$ & 0.256 & 0.126 & 0.315 & 0.168 & 0.330 & 0.170 & 0.335 & 0.153 & 0.295 & 0.135 & 0.274 & 0.086 & 0.256 & 0.075 \\
\hline & R P & 0.409 & 0.097 & 0.478 & 0.253 & 0.460 & 0.232 & 0.475 & 0.245 & 0.447 & 0.220 & 0.414 & 0.174 & 0.375 & 0.151 \\
\hline 色 & 温 度 & 650 & $0^{\circ} \mathrm{K}$ & 450 & & 450 & $0^{\circ} \mathrm{K}$ & 4500 & $0^{\circ} \mathrm{K}$ & 4500 & $0^{\circ} \mathrm{K}$ & 6500 & $0^{\circ} \mathrm{K}$ & 6500 & ${ }^{\circ} \mathrm{K}$ \\
\hline
\end{tabular}

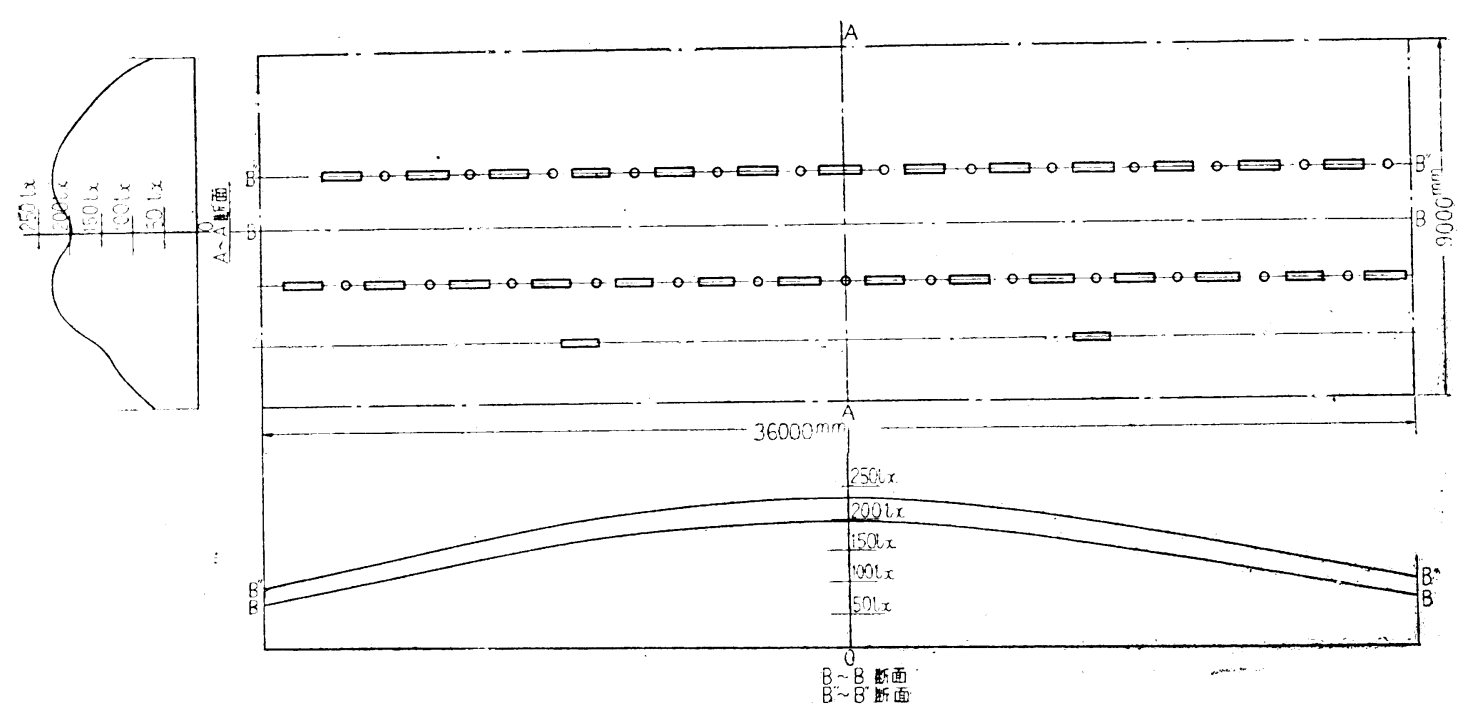

别図 $40 \mathrm{~W} 1$ 灯用反射笠付 F 421 (等照实曲線经初光束の場合を示す) 